\title{
Development of Concrete Paving Blocks Prepared from Waste Materials without Portland Cement
}

\author{
Charin NAMARAK, Chaiwut BUMRUNGSRI, Weerachart TANGCHIRAPAT, \\ Chai JATURAPITAKKUL *
}

Department of Civil Engineering, Faculty of Engineering, King Mongkut's University of Technology Thonburi, Bangkok
10140, Thailand

crossref http://dx.doi.org/10.5755/j01.ms.24.1.17566

Received 08 February 2017; accepted 23 June 2017

\begin{abstract}
This experiment used three types of waste materials: calcium carbide residue, fly ash, and recycled concrete aggregate to develop concrete paving blocks. The blocks had calcium carbide residue and fly ash as a binder without ordinary Portland cement $(\mathrm{OPC})$ and combined with $100 \%$ of recycled concrete aggregate. The concrete paving blocks were $10 \times 10 \times 20 \mathrm{~cm}$ and were formed using a pressure of 6 or $8 \mathrm{MPa}$. The binder-to-aggregate ratio was held constant at 1:3 by weight, while the water-to-binder ratios were $0.30,0.35$, and 0.40 . The effects of the water-to-binder ratios and fineness of the binder on the compressive strength, flexural strength, abrasion resistance, and water absorption of the concrete paving blocks were determined and compared with those of TIS 827 and ASTM C1319 standards. The results revealed that by applying this procedure, we were able to produce an excellent concrete paving block without using OPC. The compressive strength of the concrete paving blocks made from these waste materials was $41.4 \mathrm{MPa}$ at 28 days and increased to $45.3 \mathrm{MPa}$ at 60 days. Therefore, these waste materials can be used as raw materials to manufacture concrete paving blocks without OPC that meet the requirements of $40 \mathrm{MPa}$ and $35 \mathrm{MPa}$ specified by the TIS 827 and ASTM C1319 standards, respectively.

Keywords: calcium carbide residue, recycled concrete aggregate, concrete paving block, waste material, compressive strength.
\end{abstract}

\section{INTRODUCTION}

Concrete paving blocks are one of the most widely used construction materials in the world. Because they are easy to install, strong, durable, inexpensive, weather resistant, and fireproof, they are well suited for building roads, pavements, and car parks. One major advantage of using concrete paving blocks is that they can be re-assembled easily using many construction techniques so that they can be re-used or rearranged in different shapes or for different tasks rather than being used once and then destroyed, as is the normal practice. However, their quality depends on the composition of the base and sub-base layers that must be suitably formulated for different applications using a mixture of Portland cement and water with various types of fine aggregates. There are many types of concrete paving blocks such as the herringbone pattern, stretcher bond, and basket-weave. According to the ASTM C1319 standard [1], the compressive strength of concrete paving blocks should be greater than $35 \mathrm{MPa}$ and the water absorption should be not more than $160 \mathrm{~kg} / \mathrm{m}^{3}$.

At the present time, the demand for concrete paving blocks is growing and contributing to increasing cement consumption. The cement production process causes both direct and indirect negative environmental impacts. Manufacturing one ton of cement involves heating the raw materials to around $1500{ }^{\circ} \mathrm{C}$ and produces approximately $900 \mathrm{~kg}$ of carbon dioxide $\left(\mathrm{CO}_{2}\right)$ that is released into the environment [2] and becomes a major contributor to global warming. In addition, the cement production process creates a large amount of dust that affects the surrounding environment and natural resources.

\footnotetext{
* Corresponding author. Tel.: +66-2-470-9314; fax: +66-2-427-9063.

E-mail address: chaijatura58@gmail.com (C. Jaturapitakkul)
}

Thus, to reduce the Portland cement consumption, it is advantageous to use substitute materials, such as fly ash or natural pozzolans. Additionally, previous researches have investigated the use or development of alternative binders that are more environmentally friendly and that can be used to replace Portland cement in concrete production [3-14].

Calcium carbide residue (CCR) is a waste product of the acetylene $) \mathrm{C}_{2} \mathrm{H}_{2}$ ) gas production process. Acetylene $) \mathrm{C}_{2} \mathrm{H}_{2}$ ) gas is widely used for welding in industry and ripening fruits in agriculture, while $\mathrm{CCR}$, in the form of $\mathrm{Ca}(\mathrm{OH})_{2}$, is often a discarded factory waste because its high alkalinity affects landfills and the surrounding areas. Fig. 1 shows the amount of CCR discarded in a landfill between 2004 and 2015 by an acetylene gas factory in the central region of Thailand. Approximately 1.000 tons per month, or 12.000 tons per year, of CCR is sent to the disposal area. Previous research has found that $\mathrm{CCR}$ can react with pozzolanic materials to produce materials with cementitious properties [15].

Fly ash, or pulverized fuel ash, is the ash resulting from burning pulverized coal in coal-fired electricity power stations. It is a type of pozzolanic material primarily consisting of silica and alumina oxides that can be used as a cement replacement in concrete and can improve the properties of concrete [16-18]. For example, fly ash can increase the workability of concrete, decrease the effects of concrete segregation, reduce the heat of hydration and the permeability of water, and enhance the durability of the concrete. In addition to these benefits, fly ash increases the long term compressive strength of concrete. The use of fly ash as a cement substitute in concrete also decreases the amount 
of OPC required. However, the amount of fly ash used as cementitious material in concrete is low when compared to its total production volume. The quantity of discarded fly ash is increasing, as is the resulting environmental pollution it causes in the areas surrounding the disposal sites.

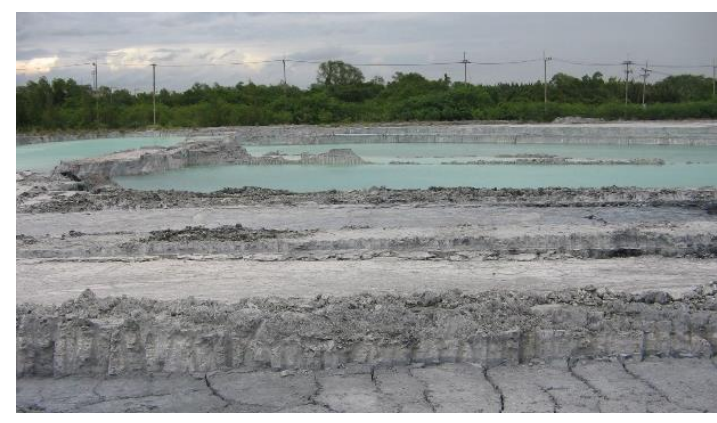

a

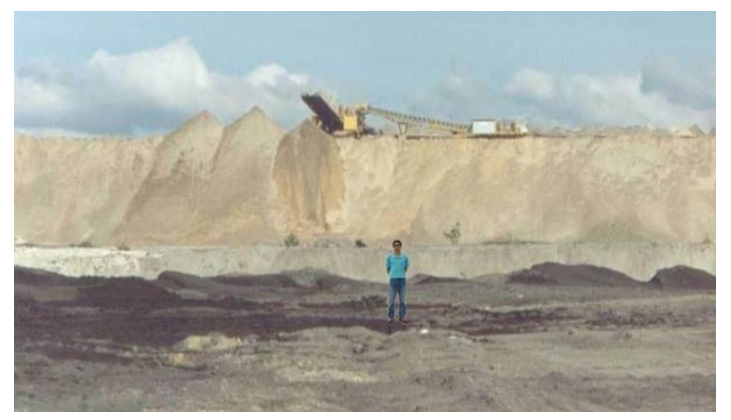

b

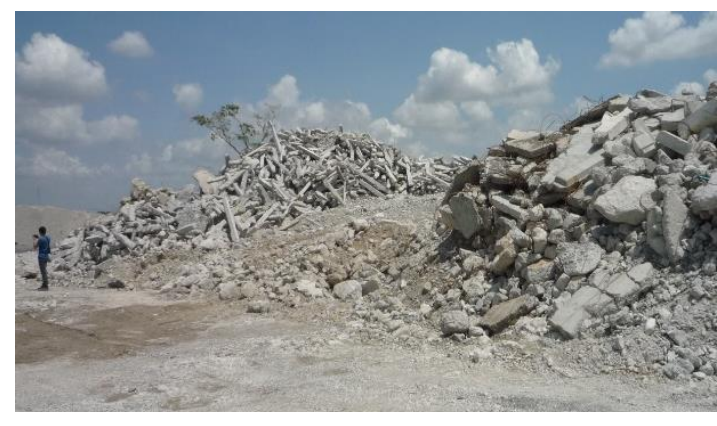

$\mathrm{c}$

Fig. 1. Disposal areas for calcium carbide residue, fly ash, and recycled concrete aggregate: a-calcium carbide residue disposal area; $\mathrm{b}$-fly ash disposal area; $\mathrm{c}$ - recycled concrete aggregate disposal area

Recycled concrete aggregate (RCA) is a product that is made by crushing waste concrete such as cut foundation piles, concrete construction/demolition debris, and other sources. Disposing of crushed concrete also produces some adverse environmental effects and entails a substantial cost. Approximately 60 to 75 percent the total volume of a concrete mixture is coarse aggregate. Therefore, utilizing RCA would not only reduce the area needed for waste disposal, but also offer a way to reduce the use of natural materials. However, RCA is not widely used in practice due to the lack of confidence in its quality and insufficient knowledge and understanding of its application. Thus, many researchers have conducted studies on the use of RCA in concrete, and their results have revealed that recycled concrete aggregate can reduce the mechanical and durability properties of the concrete $[19,20]$. The drying shrinkage, creep, and water absorption of RCA concrete are also higher, and its compressive strength is lower. In addition, RCA has a higher porosity, the values of slump loss, Los Angeles abrasion (LA) test and aggregate crushing value (ACV) are also higher than those of natural stones [21]. Although, the properties of RCA may change in relation to its source, it still can be used in concrete. Poon [22, 23] suggested that pozzolanic materials can increase the compressive strength and durability qualities of concrete that includes RCA in its mixture. Most previous studies that have been conducted with RCA as the coarse aggregate in concrete have produced positive results. Conversely, it is less frequently used as the fine aggregate in concrete because of negative findings relating it to high levels of water absorption. Therefore, this research investigated the possibility of using finely ground recycled concrete aggregate as a substitute for crushed limestone dust in the production of concrete paving blocks.

Due to the effects of waste materials on the environment and the demand for concrete paving blocks for construction, this study was focused on the development of a process using a mixture of three common wastes, CCR, fly ash, and RCA as the raw materials to produce concrete paving blocks. The purpose of the study was to investigate the alternative of using waste materials in concrete paving block production, employing CCR and fly ash as a binder without OPC and using RCA as the aggregate. The results of the study could contribute greatly to the effort of reducing environmental problems by decreasing the impact related to cement production and giving value to these waste materials, thereby diverting them from landfills. Also, the paving blocks from these materials are not waste materials anymore because they do not contribute to the contamination of the Earth. In addition, the results revealed that this process not only reduced the amount of cement and natural aggregate needed but also reduced the cost of paving block production and the cost of waste management. Health problems and environmental pollution caused by these waste materials and from concrete manufacturing could also be reduced. Moreover, using a mixture of CCR, fly ash, and RCA as alternative raw materials for concrete paving block production can conserve natural construction materials for long-term use. Significantly, using less cement in concrete paving block production greatly reduces the amount of $\mathrm{CO}_{2}$ released in the atmosphere resulting from the production of OPC. Overall, it can be seen that this approach can provide both economic and environmental gains.

\section{EXPERIMENTAL PROGRAM}

\subsection{Materials}

The main materials used in this study consisted of calcium carbide residue (CCR), fly ash, recycled concrete aggregate (RCA), and water.

\subsubsection{Binders}

A mixture of CCR and fly ash was used as the binder to produce concrete paving blocks because a combination of these two materials has the potential to be used as a binder that provides features similar to those of OPC [3, 24]. The physical properties and chemical composition of CCR and fly ash are presented in Table 1 and Table 2, respectively. 
The CCR used throughout this study was obtained from the disposal area of an acetylene gas factory in Samut Sakhon Province, Thailand (see Fig. 1 a). Since the CCR was received directly from the factory, it contained an excessive amount of water (approximately 50\%). Therefore, it was placed in a dry sunny area to allow the water to evaporate naturally for 3-4 days to reduce the water content prior to drying at a temperature of $110 \pm 5^{\circ} \mathrm{C}$ for $24 \mathrm{~h}$. The fly ash (FA) was collected from a thermal power plant in Mae Moh District, Lampang Province, Thailand (see Fig. 1 b). Although approximately 2.3 million tons of fly ash per year are used in Thailand as a pozzolanic material to produce concrete, it has not been used as a main cementitious material. Thus, using fly ash as an alternative to other cementitious materials would prove to be greatly beneficial.

CCR and FA were mixed in a ratio of $30: 70$ by weight as reported by Krammart [25] to be the optimum ratio. Next, they were ground in a ball mill until less than $5 \%$ of particles by weight were retained on a No. 325 sieve and designated as GCF.

Table 1. Physical properties of the materials

\begin{tabular}{|l|c|c|c|c|}
\hline \multirow{2}{*}{ Properties } & \multicolumn{2}{|c|}{ Original } & \multicolumn{2}{c|}{ Ground } \\
\cline { 2 - 5 } & CR & FA & CCR & FA \\
\hline Specific Gravity & 2.32 & 2.34 & 2.47 & 2.39 \\
\hline Retained on a Sieve No. 325, \% & - & 48.6 & 2.3 & 0.6 \\
\hline Median Particle Size, d50 (microns) & - & 32.3 & 8.6 & 9.2 \\
\hline
\end{tabular}

Table 2. Chemical composition of the materials

\begin{tabular}{|l|c|c|}
\hline \multicolumn{1}{|c|}{ Properties, \% } & CCR & Fly ash \\
\hline Silicon dioxide $\left(\mathrm{SiO}_{2}\right)$ & 4.3 & 44.6 \\
\hline Aluminium oxide $\left(\mathrm{Al}_{2} \mathrm{O}_{3}\right)$ & 0.4 & 23.5 \\
\hline Ferric oxide $\left(\mathrm{Fe}_{2} \mathrm{O}_{3}\right)$ & 0.9 & 10.4 \\
\hline Calcium oxide $(\mathrm{CaO})$ & 56.5 & 13.8 \\
\hline Magnesium oxide $(\mathrm{MgO})$ & 1.7 & 3.3 \\
\hline Sodium oxide $\left(\mathrm{Na}_{2} \mathrm{O}\right)$ & 0.0 & 0.1 \\
\hline Potassium oxide $\left(\mathrm{K}_{2} \mathrm{O}\right)$ & 0.0 & 2.6 \\
\hline Sulfur trioxide $\left(\mathrm{SO}_{3}\right)$ & 0.1 & 1.2 \\
\hline Loss on ignition $(\mathrm{LOI})$ & 36.1 & 0.8 \\
\hline
\end{tabular}

Table 3. Physical properties of the aggregate

\begin{tabular}{|l|c|c|}
\hline \multicolumn{1}{|c|}{ Properties } & River sand & RFA \\
\hline Fineness modulus & 3.07 & 3.27 \\
\hline Bulk specific gravity & 2.62 & 2.40 \\
\hline Absorption, \% & 0.91 & 6.46 \\
\hline Dry-rodded weight, $\mathrm{kg} / \mathrm{m}^{3}$ & 1725 & 1485 \\
\hline
\end{tabular}

\subsubsection{Fine recycled concrete aggregate}

Fine recycled concrete aggregate was obtained from cylindrical concretes, which were tested in King Mongkut's University of Technology Thonburi Concrete Laboratory, Thailand. Their compressive strengths were between 25 and $40 \mathrm{MPa}$ according to the tests using swing hammer mills. The recycled aggregate that was obtained from the crushed cylindrical concretes was sieved to separate coarse aggregate from fine aggregate using a No. 4 sieve. The aggregate that passed through the No. 4 sieve was used as the material in the study (designated as RFA). The physical properties of recycled fine aggregate (RFA) obtained from the crushed cylindrical concretes, are shown in Table 3.

\subsection{Mix proportions and concrete paving block production}

The binders used for concrete paving block production in this study were divided into two groups i.e., ground and unground. The ground binder group used three different water-to-binder (W/B) ratio values, 0.30, 0.35, and 0.40, while the unground group used a W/B ratio of 0.35 . However, both groups used the same binder to RFA ratio of 1:3 by weight. The mix proportions for the concrete paving blocks are presented in Table 4.

Table 4. Mix proportions of the concrete paving blocks

\begin{tabular}{|l|c|c|c|c|}
\hline \multirow{2}{*}{ Blocks I.D. } & \multicolumn{2}{|c|}{ Mixture Proportion, by weight } & \multirow{2}{*}{ W/B } \\
\cline { 2 - 4 } & CCR & FA & RFA & \\
\hline 40GCF6/40GCF8 & 0.3 & 0.7 & 3 & 0.40 \\
\hline 35GCF6/35GCF8 & 0.3 & 0.7 & 3 & 0.35 \\
\hline 30GCF6/30GCF8 & 0.3 & 0.7 & 3 & 0.30 \\
\hline 35OCF6 & 0.3 & 0.7 & 3 & 0.35 \\
\hline
\end{tabular}

To produce the concrete paving blocks the concrete paving block mixtures were put into prepared molds with dimensions of $10 \times 10 \times 20 \mathrm{~cm}$. The concrete mixtures were divided equally into three layers. The first two layers were tamped down using a $5 \times 5 \times 2 \mathrm{~cm}$ steel plate to compact them. After placing the third layer into the molds, the molded concrete paving blocks were compressed using a universal testing machine (UTM) at a pressure of 6 or $8 \mathrm{MPa}$ (see Fig. 2). Next, the concrete paving blocks were removed from the molds and held at room temperature for $24 \mathrm{~h}$. Finally, they were cured in water until the age of testing.

\subsection{Testing properties}

The compressive strengths of the concrete paving blocks were determined at ages of 7, 14, 28, and 60 days according to ASTM C140 [26]. Three samples were used to obtain the average value of the compressive strength at each age according to ASTM C39 [27].

The water absorption values of the concrete paving blocks were investigated at the age of 28 days according to ASTM C140 [26]. The blocks were heated to $110 \pm 5{ }^{\circ} \mathrm{C}$ for $48 \mathrm{~h}$ and then allowed to cool at room temperature prior to being soaked in water for 24 hours. The water absorption was calculated by comparing the saturated and oven-dry weights of the blocks and determining the amount of water that had been absorbed.

The flexural strength values of the $10 \times 10 \times 20 \mathrm{~cm}^{3}$ concrete paving blocks were investigated using the threepoint bending test with a $15 \mathrm{~cm}$ span length at the ages of 7 , 28, and 60 days according to ASTM C293 [28]. Three samples were used to obtain the average value of the bending stress of the blocks.

The abrasion resistance values of the concrete paving blocks were investigated by applying a rotating-cutter method at the ages of 28 and 60 days according to ASTM C944 [29]. The specimens were fixed in the holding device of the abrasion machine (rotating-cutter), and a normal load of $98 \mathrm{~N}$ was applied. The abrasion machine was then put in motion at a speed of $200 \mathrm{rpm}$. The test were conducted for $12 \mathrm{~min}$ to determine the amount of mass loss. Three concrete specimens were tested to obtain the average value for each data set. 


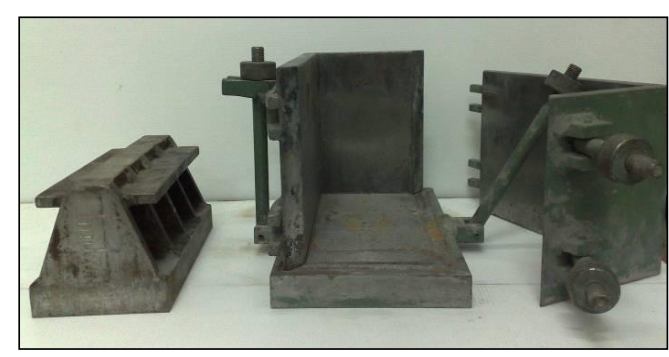

$\mathrm{a}$

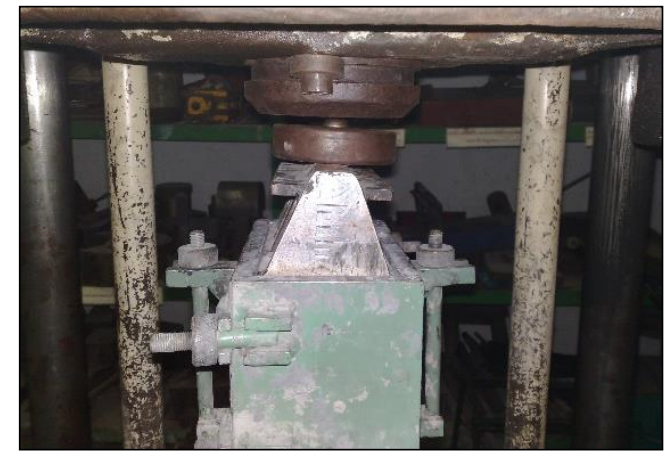

b

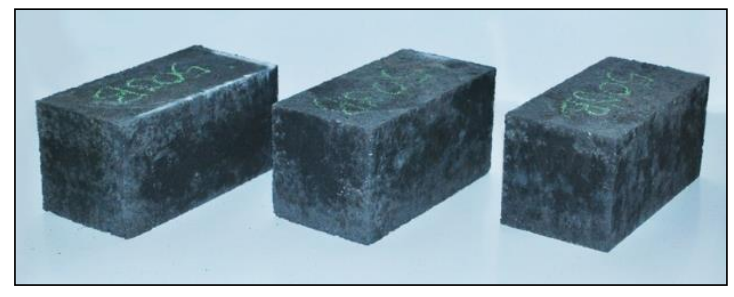

$\mathrm{c}$

Fig. 2. Forming concrete paving blocks: a - concrete paving block mold; $\mathrm{b}$ - an universal testing machine was used to create a pressure of 6 or $8 \mathrm{MPa}$ on the concrete paving blocks; $\mathrm{c}$-concrete paving blocks

\section{RESULTS AND DISCUSSION}

\subsection{Water absorption of concrete paving block}

Water absorption is one of factors that affects the durability of concrete. Concrete that have a high water absorption valve will have low chloride resistance and low sulfate resistance as well as low water penetration resistance. According to Table 5, 40GCF6, 35GCF6, 30GCF6, and 35OCF6 concrete paving blocks had water absorptions values of $146,154,195$ and $222 \mathrm{~kg} / \mathrm{m}^{3}$ or equal to $7.04,7.53,10.21$, and $12.47 \%$ by weight, respectively. Therefore, 40GCF6 and 35GCF6 blocks are compatible with ASTM C1319 [1] in that their water absorption is not more than $160 \mathrm{~kg} / \mathrm{m}^{3}$. Water absorption is dependent on the density of sample and when the densities increased, the water absorption values of the concrete paving blocks drops.

Comparison of the blocks produced using the ground and unground binders (35GCF6 and 35OCF6) revealed that the blocks produced using the ground binder had substantially lower water absorption than those one made using the unground binder. This is due to the fact that the fineness of the binder had a direct effect on the water absorption values. Increasing the fineness of the binder increased the density of the concrete paving blocks. This can be understood because the concrete paving blocks will be denser, less porous, and have a lower water absorption values. In addition, because of the smaller particles, the pozzolanic reaction between the CCR and FA can reduce the porosity of the binder gel [30]. As a result, concrete paving blocks manufactured with an unground binder material will have higher porosity, lower density and fineness and a higher water absorption values than those manufactured with a ground binder.

Additionally, increasing the forming pressure on concrete paving blocks from $6 \mathrm{MPa}$ to $8 \mathrm{MPa}$ slightly increased the density, but the water absorption values did not differ significantly. For example, the 40GCF6 concrete paving blocks that were made using a forming pressure of $6 \mathrm{MPa}$ had a density of $2075 \mathrm{~kg} / \mathrm{m}^{3}$ and a water absorption value of $7.04 \%$, while the $40 \mathrm{GCF} 8$ paving blocks that were made using a forming pressure of $8 \mathrm{MPa}$ had a density of $2095 \mathrm{~kg} / \mathrm{m}^{3}$ and the water absorption of $7.02 \%$. This result indicates that a water-to-binder ratio of 0.40 is sufficient to increase the density of concrete paving blocks and thus lower the water absorption values. The water absorption values of the concrete paving blocks were approximately $7-13 \%$. These values were inversely related to the densities of the concrete paving blocks.

Table 5. Water absorption of the concrete paving blocks at the age of 28 days

\begin{tabular}{|c|c|c|c|}
\hline $\begin{array}{l}\text { Blocks } \\
\text { I.D. }\end{array}$ & $\begin{array}{c}\text { Oven-dry } \\
\text { W/volume, } \\
\mathrm{kg} / \mathrm{m}^{3}\end{array}$ & $\begin{array}{c}\text { Absorption/volume, } \\
\mathrm{kg} / \mathrm{m}^{3}\end{array}$ & $\begin{array}{c}\text { Water absorption, } \\
\text { wt. } \%\end{array}$ \\
\hline 40GCF6 & 2075 & 146 & 7.04 \\
\hline $35 \mathrm{GCF} 6$ & 2045 & 154 & 7.53 \\
\hline $30 \mathrm{GCF} 6$ & 1914 & 195 & 10.21 \\
\hline $40 \mathrm{GCF} 8$ & 2095 & 147 & 7.02 \\
\hline $35 \mathrm{GCF} 8$ & 2045 & 158 & 7.73 \\
\hline 30GCF8 & 2015 & 163 & 8.09 \\
\hline $35 \mathrm{OCF} 6$ & 1775 & 222 & 12.47 \\
\hline \multicolumn{4}{|c|}{$\begin{array}{l}\text { Note: } \\
\text { xxOCFy = original CCR-FA with W/B } 0 . x x \text { and y MPa for casting } \\
\quad \text { pressure } \\
\text { xxGCFy = ground CCR-FA with W/B } 0 . x x \text { and y MPa for casting } \\
\text { pressure } \\
\text { For example, } 35 \mathrm{GCF} 8=\text { concrete paving block using a ground CCR-FA } \\
\text { mixture as a binder, a W/B ratio of } 0.35 \text {, and a forming pressure of } 8 \mathrm{MPa}\end{array}$} \\
\hline
\end{tabular}

\subsection{Effects of water to binder ratio on compressive strength}

According to Fig. 3, the results show that at 7, 28, and 60 days, the $35 \mathrm{GCF} 6$ concrete paving blocks with a W/B ratio of 0.35 had compressive strengths of 21, 36.6, and 42.4 MPa, respectively. These concrete paving blocks also had the highest compressive strengths because the pressure used during forming was sufficiently high $(6 \mathrm{MPa})$ to increase the density and reduce the porosity of the blocks, as well as eliminate unwanted water [31].

The 40GCF6 concrete paving blocks with a W/B ratio of 0.40 had compressive strengths of 20.5, 36.2, and $40.8 \mathrm{MPa}$ at 7,28, and 60 days, respectively, indicating that using an excessive amount of water resulted in decreased compressive strengths. The weakest compressive strengths were observed in $30 \mathrm{GCF} 6$ concrete paving blocks that were 15.0, 26.5, and 29.6 MPa at 7, 28, and 60 days, respectively. This demonstrated that using an insufficient amount of 
water in the concrete mixture resulted in unequal compression and a lower density of the concrete paving blocks, and thus, the corresponding compressive strengths were lower than those of the blocks using a W/B ratio of 0.35 . Therefore, a W/B ratio of 0.35 is considered to be the most appropriate ratio to enable the best compression for producing concrete paving blocks. It should also be noted that using a $\mathrm{W} / \mathrm{B}$ ratio that is too low results in insufficient compaction and insufficient water for the concrete reaction. Likewise, the density and the compressive strengths in concrete paving blocks may be reduced because of the porosity caused by a W/B ratio that is too high.

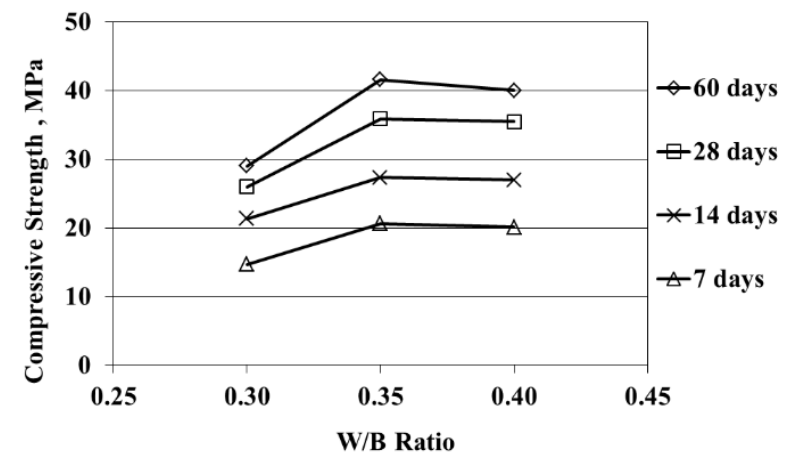

Fig. 3. Relationship between compressive strength and W/B ratio of concrete paving blocks formed at a pressure of $6 \mathrm{MPa}$

Overall, the compressive strengths of the 40GCF6, $35 \mathrm{GCF} 6$, and $30 \mathrm{GCF} 6$ concrete paving blocks increased as their curing ages increased. Additionally, the 40GCF6 and 35GCF6 concrete paving blocks developed similar compressive strengths because they used W/B ratios of 0.40 and 0.35 , respectively. However, more water was expelled from the concrete paving blocks with a $0.40 \mathrm{~W} / \mathrm{B}$ ratios than from the blocks using a $0.35 \mathrm{~W} / \mathrm{B}$ ratio during the forming process. The expulsion of water during the molding process made the W/B ratio of the mixtures similar with respect to the water available for the concretion reactions. As a result, the compressive strengths of the concrete paving blocks using W/B ratios of 0.35 and 0.40 were not very different. Conversely, the compressive strengths of the 30GCF6 concrete paving blocks using a W/B ratio of 0.30 , resulting in a dry concrete mixture, were substantially different. This low W/B ratio led to low compressive strengths and low densities in the concrete paving blocks. Additionally, the compressive strength increases at different ages were less than those of the concrete paving blocks having W/B ratios of 0.40 and 0.35 .

The compressive strengths at 28 days of 40GCF6, 35GCF6, 40GCF8, and 35GCF8 concrete paving blocks were $36.2,36.6,36.9$, and $41.4 \mathrm{MPa}$, respectively, as presented in Table 6. It should be noted that the 35GCF8 concrete paving blocks had an average compressive strength greater than $40 \mathrm{MPa}(41.4 \mathrm{MPa})$. In addition, all of these compressive strengths are higher than the minimum requirement of ASTM $\mathrm{C} 1319$ that, states that the compressive strength should not be less than $35 \mathrm{MPa}$. Therefore, all of these samples of concrete paving blocks exceed the minimum requirement for compressive strength as defined by ASTM C 1319 [1]. At 60 days, the compressive strengths of 40GCF6, 35GCF6, 40GCF8, and $30 \mathrm{GCF} 8$ concrete paving blocks were $40.8,42.4,41.8$, and
43.7 MPa, respectively. Thus, the test results for these concrete paving blocks are consistent with Thai Industrial Standard TIS 827 [32] that requires that the compressive strength of concrete paving blocks must be higher than $40 \mathrm{MPa}$.

\subsection{Effects of fineness of binder on the compressive strength}

The 350CF6 concrete paving blocks that were manufactured with unground binder had compressive strengths of 9.0, 18.7, and 23.6 MPa, at 7, 28, and 60 days, respectively, as presented in Table 6 . The 35GCF6 concrete paving blocks that were manufactured with ground CCRFA had substantially higher compressive strengths of 21.0, 36.6, and $42.4 \mathrm{MPa}$ at 7, 28, and 60 days, respectively. This demonstrated that the fineness of the binder had a strong and direct effect on the compressive strengths of the concrete paving blocks. At 60 days, 35GCF6 concrete paving blocks had an average compressive strength of $42.4 \mathrm{MPa}$, while the average value of the $350 \mathrm{OCF} 6$ concrete paving blocks was merely $23.6 \mathrm{MPa}$, which is approximately 1.8 times lower. Because the unground CCR and FA had large particles, the reaction of the two materials was slowed, resulting in the lower compressive strength [3]. This finding supports the previous research of Sata et al. [5] that showed that grinding can enhance the compressive strength of concrete containing pozzolan. However, unground calcium carbide residue-fly ash could be used for Grade B concrete production because the Thai Industrial Standard TIS 59 [33] only requires a compressive strength of $17.5 \mathrm{MPa}$.

Table 6. Compressive strength of the concrete paving blocks

\begin{tabular}{|c|c|c|c|c|}
\hline \multirow[t]{2}{*}{ Blocks } & \multicolumn{4}{|c|}{$\begin{array}{c}\text { Compressive strength, } \mathrm{MPa} \\
\text { - Percentage compressive strength }\end{array}$} \\
\hline & 7 days & 14 days & 28 days & 60 days \\
\hline TIS-827 & $\begin{array}{c}40.0-1 \\
00\end{array}$ & $\begin{array}{c}40.0-1 \\
00\end{array}$ & $\begin{array}{c}40.0-1 \\
00\end{array}$ & $\begin{array}{c}40.0-1 \\
00\end{array}$ \\
\hline $450 \mathrm{OCF} 6$ & $9.3-23$ & $\begin{array}{c}17.0-4 \\
3\end{array}$ & $\begin{array}{c}21.3-5 \\
3\end{array}$ & $\begin{array}{c}27.6-6 \\
9\end{array}$ \\
\hline $400 \mathrm{OCF} 6$ & $\begin{array}{c}11.8-3 \\
0\end{array}$ & $\begin{array}{c}17.5-4 \\
4\end{array}$ & $\begin{array}{c}22.3-5 \\
6\end{array}$ & $\begin{array}{c}28.8-7 \\
2\end{array}$ \\
\hline $35 \mathrm{OCF} 6$ & $9.0-23$ & $\begin{array}{c}14.2-3 \\
6\end{array}$ & $\begin{array}{c}18.7-4 \\
7\end{array}$ & $\begin{array}{c}23.6-5 \\
9\end{array}$ \\
\hline 40GCF6 & $\begin{array}{c}20.5-5 \\
1\end{array}$ & $\begin{array}{c}27.5-6 \\
9\end{array}$ & $\begin{array}{c}36.2-9 \\
1\end{array}$ & $\begin{array}{c}40.8-1 \\
02\end{array}$ \\
\hline 35GCF6 & $\begin{array}{c}21.0-5 \\
3\end{array}$ & $\begin{array}{c}27.8-7 \\
0\end{array}$ & $\begin{array}{c}36.6-9 \\
2\end{array}$ & $\begin{array}{c}42.4-1 \\
06\end{array}$ \\
\hline 30GCF6 & $\begin{array}{c}15.0-3 \\
8\end{array}$ & $\begin{array}{c}21.7-5 \\
4\end{array}$ & $\begin{array}{c}26.5-6 \\
6\end{array}$ & $\begin{array}{c}29.6-7 \\
4\end{array}$ \\
\hline 40GCF8 & $\begin{array}{c}20.3-5 \\
1\end{array}$ & $\begin{array}{c}27.9-7 \\
0\end{array}$ & $\begin{array}{c}36.9-9 \\
2\end{array}$ & $\begin{array}{c}41.8-1 \\
05\end{array}$ \\
\hline $35 \mathrm{GCF} 8$ & $\begin{array}{c}21.2-5 \\
3\end{array}$ & $\begin{array}{c}33.6-8 \\
4\end{array}$ & $\begin{array}{c}41.4-1 \\
04\end{array}$ & $\begin{array}{c}45.3-1 \\
13\end{array}$ \\
\hline 30GCF8 & $\begin{array}{c}20.9-5 \\
2\end{array}$ & $\begin{array}{c}26.6-6 \\
7\end{array}$ & $\begin{array}{c}35.6-8 \\
9\end{array}$ & $\begin{array}{c}43.7-1 \\
09\end{array}$ \\
\hline
\end{tabular}

\subsection{Flexural strength of concrete paving blocks}

The flexural strength of the concrete paving block specimens that exhibited the highest compressive strength in each group, i.e., 35GCF6, 35OCF6, and 35GCF8, were determined, and the results are presented in Table 7. It was found that the flexural strengths of the concrete paving blocks using ground binder were higher than those using the 
unground binder. Moreover, the increases of the flexural strengths tended to correlate with increases in the curing age and compressive strengths. The flexural strengths of $35 \mathrm{GCF} 6$ concrete paving blocks at 7, 28, and 60 days were 3.6, 4.1, and 4.7 MPa, respectively, while those of 35OCF6 concrete paving blocks were $1.5,3.7$, and $4.0 \mathrm{MPa}$, respectively. At the same ages, the flexural strengths of the blocks were approximately $11-20 \%$ of their compressive strengths, and they gradually increased along with the increase of their compressive strengths. Thus, it can be seen that the different compressive strengths resulting from the forming pressures used in producing the concrete paving blocks had little effect on their flexural strength. In other words, increasing the forming pressure from $6.0 \mathrm{MPa}$ (35GCF6 block) to 8.0 MPa (35GCF8) did not increase its flexural strength as a percentage of the compressive strength.

Table 7. Results of the flexural strength test of the concrete paving blocks

\begin{tabular}{|c|c|c|c|}
\hline \multirow{2}{*}{ Blocks } & \multicolumn{3}{|c|}{ Flexural strength, MPa } \\
& \multicolumn{2}{|c|}{ - Percentage of compressive strength } \\
\cline { 2 - 4 } & 7 days & 28 days & 60 days \\
\hline 35GCF6 & $3.6-17$ & $4.1-11$ & $4.7-11$ \\
\hline 35OCF6 & $1.5-17$ & $3.7-20$ & $4.0-17$ \\
\hline 35GCF8 & $3.5-17$ & $4.4-11$ & $4.8-11$ \\
\hline
\end{tabular}

\subsection{Abrasion resistance}

The results of the abrasion resistance tests of the concrete paving blocks at 28 and 60 days are presented in Fig. 4.

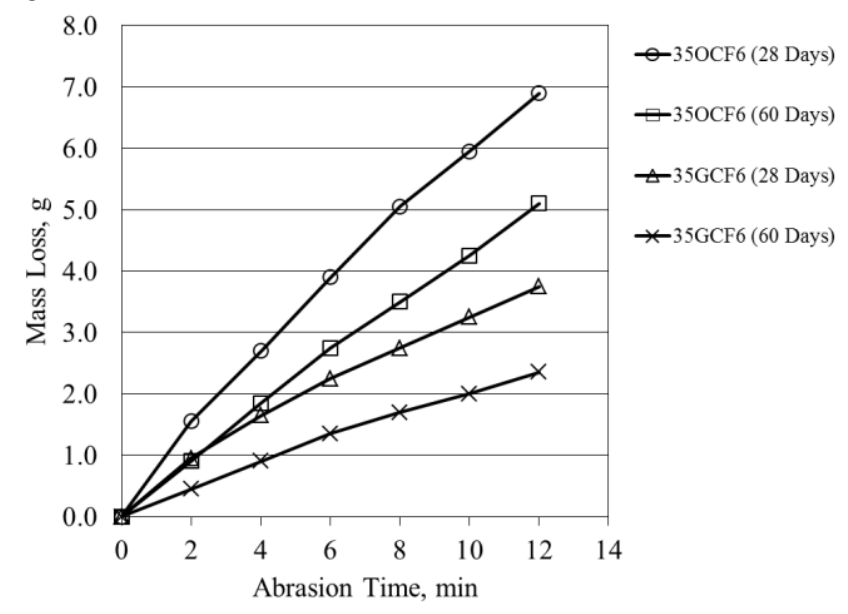

Fig. 4. Loss of concrete paving block mass during abrasion resistance testing

The 35GCF6 concrete paving blocks had mass loss values of 3.75 and $2.35 \mathrm{~g}$ at 28 and 60 days, respectively, while the mass loss values of the $350 \mathrm{OCF} 6$ concrete paving blocks were 6.90 and $5.10 \mathrm{~g}$, respectively. The mass loss values decreased as the compressive strengths of the blocks increased with the increases of the fineness of the binder and the curing age. Therefore, increasing the fineness of the binder reduced the mass loss from abrasion. Likewise, the increased block age and high fineness of the binder might yield higher compressive strengths in addition to a lower mass loss [34]. Furthermore, the 35GCF8 concrete paving blocks had less mass loss than normal concrete paving blocks [35]. The 35GCF8 concrete paving blocks had an average compressive strength of $41.4 \mathrm{MPa}$ and a mass loss value of $1.4 \mathrm{~g}$ over $6 \mathrm{~min}$ of testing at the age of 28 days while normal concrete paving blocks (43.5 MPa) had a greater mass loss value ( $4.1 \mathrm{~g}$ ) from the abrasion assistance test.

By considering the mass losses of 35GCF6, 35GCF8, and $35 \mathrm{OCF} 6$ concrete paving blocks in Fig. 5, it appears that increased compressive strength results in a decrease of the mass loss values. This result supports the research of Naik and et al. [36] that the abrasion resistance of concrete paving block depended upon its compressive strength. In other words, a higher compressive strength would result in a reduction of the mass loss. However, at compressive strengths ranging from $40-50 \mathrm{MPa}$, the experimental concrete paving blocks had slightly higher mass loss values than conventional concrete.

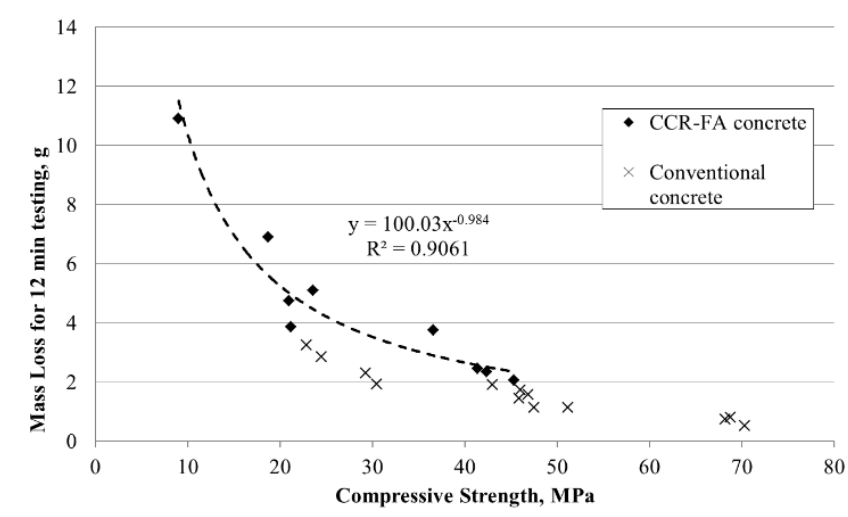

Fig. 5. Loss of mass of concrete paving block from abrasion resistance test

\section{CONCLUSIONS}

After investigating the qualities of concrete paving blocks manufactured using a mixture of calcium carbide residue, fly ash, and recycled concrete aggregate, the findings were as follows:

1. It is possible to use a calcium carbide residue-fly ash mixture as the binder and recycled concrete aggregate as the aggregate to manufacture concrete paving blocks without Portland cement. These blocks are environmentally friendly and convert waste materials into value-added materials. The compressive strengths of the resulting concrete paving blocks were increased as the curing age increased. In addition, finely grinding the binder resulted in a substantial increase of the compressive strengths of the resulting concrete paving blocks.

2. Concrete paving blocks produced using a mixture of ground calcium carbide residue-fly ash as the binder and recycled crushed concrete as a fine aggregate with forming pressure of 6 and $8 \mathrm{MPa}$ increased the compressive strengths from $42.4 \mathrm{MPa}$ to $45.3 \mathrm{MPa}$. These values are higher than required under ASTM C1319 [1] (e.g., not less than $35 \mathrm{MPa}$ ).

3. An unground calcium carbide residue-fly ash binder mixture is an appropriate material to produce Grade B concrete paving blocks that meet Thai Industrial Standard TIS 59 [33]. 
4. The flexural strength values of the concrete paving blocks gradually increased with increases of the compressive strength and curing age and were approximately $11-20 \%$ of the compressive strength.

5. The loss of mass values from the surface abrasion of the concrete paving blocks decreased as the compressive strengths increased. In other words, the loss of mass was inversely related to the compressive strength. In addition, increasing the fineness of the binder also reduced the mass loss caused by surface abrasion.

6. A W/B ratio of 0.35 and a forming pressure of $8 \mathrm{MPa}$ for manufacturing concrete paving blocks were the most suitable values when using a mixture of ground calcium carbide residue-fly ash as the binder without OPC and recycled crushed concrete was used as a fine aggregate.

\section{Acknowledgements}

The authors gratefully acknowledge the support from Muban Chombueng Rajabhat University under the faculty development scholarship and the Office of the Higher Education Commission of Thailand for providing research funding for King Mongkut's University of Technology Thonburi under the National Research University (NRU) project. Thanks are also extended to the Office of National Research Council of Thailand.

\section{REFERENCES}

1. ASTM C1319: Standard Specification for Concrete Grid Paving Units, ASTM International, West Conshohocken, PA. 2014.

2. Mehta, P.K. Global Concrete Industry Sustainability Concrete International 31 (2) 2009: pp. 45 -48.

3. Makaratat, N., Jaturapitakkul, C., Laosamathikul, T. Effects of Calcium Carbide Residue-Fly Ash Binder on Mechanical Properties of Concrete Journal of Materials in Civil Engineering 22 (11) 2010: pp. 1164-1170. https://doi.org/10.1061/(ASCE)MT.1943-5533.0000127

4. Rattanashotinunt, C., Thairit, P., Tangchirapat,W., Jaturapitakkul, C. Use of calcium Carbide Residue and Bagasse Ash Mixtures As A New Cementitious Material in Concrete Materials \& Design 46 (0) 2013: pp. 106-111. https://doi.org/10.1016/j.matdes.2012.10.028

5. Sata, V., Jaturapitakkul, C., Kiattikomol, K. Influence of pozzolan from Various By-Product Materials on Mechanical Properties of High-Strength Concrete Construction and Building Materials 21 (7) 2007: pp. 1589-1598. https://doi.org/10.1016/j.conbuildmat.2005.09.011

6. Sinsiri, T., Kroehong, W., Jaturapitakkul, C., Chindaprasirt, P. Assessing the Effect of Biomass Ashes with Different Finenesses on the Compressive Strength of Blended Cement Paste Materials \& Design $42(0)$ 2012: pp. $424-433$.

https://doi.org/10.1016/j.matdes.2012.06.030

7. Turanli, L., Uzal, B., Bektas, F. Effect of large Amounts of Natural Pozzolan Addition on Properties of Blended Cements Cement and Concrete Research 35 (6) 2005: pp. 1106-1111.

https://doi.org/10.1016/j.cemconres.2004.07.022
8. Solak, A. Experimental Investigation of Lime Mortar Used in Historical Buildings in Becin, Turkey Materials Science (Medžiagotyra) 22 (1) 2016: pp. 105-112. https://doi.org/10.5755/j01.ms.22.1.9022

9. Liu, S., Han, W., Zhou, W. The Role of Waste Glass Powder During the Hydration Process of Composite Cementitious Materials Materials Science (Medžiagotyra) 22 (4) 2016: pp. 536-541.

http://dx.doi.org/10.5755/j01.ms.22.4.13210

10. Gencel, O., Koksal, F., Ozel, C., Brostow, W. Combined Effects of Fly ash and Waste Ferrochromium on Properties of Concrete Construction and Building Materials 29 2012: pp. $633-640$. https://doi.org/10.1016/j.conbuildmat.2011.11.026

11. Beycloglu, A., Aruntaş, H.Y., Gencel, O., Hagg Lobland, H.E., Şamandar, A., Brostow, W. Effect of Elevated Temperatures on Properties of Blended Cements with Clinoptilolite Materials Science (Medžiagotyra) 22 (4) 2016: pp. $548-552$. http://dx.doi.org/10.5755/j01.ms.22.4.13354

12. Bajare, D., Bumanis, G., Korjakins, A. New Porous Material Made From Industrial and Municipal Waste for Building Application Materials Science (Medžiagotyra) 20 (3) 2014: pp. 333-338. http://dx.doi.org/10.5755/j01.ms.20.3.4330

13. Vaičiukynienė, D., Vaitkevičius, V., Rudžionis, Ž., Vaičiukynas, V., Navickas, A.A., Nizevičienė, D. Blended Cement Systems with Zeolitized Silica Fume Materials Science (Medžiagotyra) 22 (2) 2016: pp. 299-304. http://dx.doi.org/10.5755/j01.ms.22.2.7018

14. Martinez-Barrera, G., Vigueras-Santiago, E., Gencel, O., Hagg Lobland, H. Polymer Concretes: a Description and Methods for Modification and Improvement Journal of Materials Education 33 (1) 2011: pp. 37.

15. Jaturapitukkul, C., Roongreung, B. Cement Material from Calcium Carbide Residue-Rice Husk Ash Materials in Civil Engineering 15 (5) 2003: pp. 470-475. 10.1061/(ASCE)0899-1561(2003)15:5(470)

16. Boğa, A.R., Topçu, İ.B. Influence of fly Ash on Corrosion Resistance and Chloride Ion Permeability of Concrete Construction and Building Materials $31(0)$ 2012: pp. $258-264$. https://doi.org/10.1016/j.conbuildmat.2011.12.106

17. Nath, P., Sarker, P. Effect of Fly Ash on the Durability Properties of High Strength Concrete Procedia Engineering 14 (0) 2011: pp. $1149-1156$ https://doi.org/10.1016/j.proeng.2011.07.144

18. Gencel, O., Brostow, W., Datashvili, T., Thedford, M. Workability and Mechanical Performance of Steel FiberReinforced Self-Compacting Concrete with Fly Ash Composite Interfaces 18 (2) 2011: pp. 169-184. https://doi.org/10.1163/092764411X567567

19. Shi, C., Li, Y., Zhang, J., Li, W., Chong, L., Xie, Z. Performance enhancement of Recycled Concrete Aggregate A Review Journal of Cleaner Production 112 (1) 2016: pp. $466-472$. https://doi.org/10.1016/j.jclepro.2015.08.057

20. Uygunoğlu, T., Topcu, I.B., Gencel, O., Brostow, W. The effect of Fly Ash Content and Types of Aggregates on the Properties of Pre-Fabricated Concrete Interlocking Blocks (PCIBs) Construction and Building Materials 30 2012: pp. 180-187. https://doi.org/10.1016/j.conbuildmat.2011.12.020 
21. Lye, C.-Q., Dhir, R.K., Ghataora, G.S., Li, H. Creep Strain of Recycled Aggregate Concrete Construction and Building Materials 102 (1) 2016: pp. 244-259.

https://doi.org/10.1016/j.conbuildmat.2015.10.181

22. Kou, S.C., Poon, C.S. Long-term Mechanical and Durability Properties of Recycled Aggregate Concrete Prepared with the Incorporation of Fly Ash Cement and Concrete Composites 37 2013: pp. $12-19$.

https://doi.org/10.1016/j.cemconcomp.2012.12.011

23. Kou, S.C., Poon, C.S., Agrela, F. Comparisons of Natural and Recycled Aggregate Concretes Prepared with the Addition of Different Mineral Admixtures Cement and Concrete Composites 33 (8) 2011: pp. $788-795$. https://doi.org/10.1016/j.cemconcomp.2011.05.009

24. Amnadnua, K., Tangchirapat, W., Jaturapitakkul, C. Strength, Water Permeability, and Heat Evolution of High Strength Concrete Made from the Mixture of Calcium Carbide Residue and Fly Ash Materials \& Design 51 (0) 2013: pp. $894-901$. https://doi.org/10.1016/j.matdes.2013.04.099

25. Krammart, P., Martputhorn, S., Jaturapitakkul, C., Ngaopisadarn, V. A Study of Compressive Strength of Mortar Made from Calcium Carbide Residue and Fly Ash Research and Development Journal of the Engineering Institute of Thailand 7 (2) 1996: pp. 65-75.

26. ASTM C140: Standard Test Method for Sampling and Testing Concrete Masonry Units and Related Units, ASTM International, West Conshohocken, PA. 2011.

27. ASTM C39: Standard Test Method for Compressive Strength of Cylindrical Concrete Specimens, 2012.

28. ASTM C293: Standard Test Method for Flexural Strength of Concrete (Using Simple Beam with Center-Point Loading), ASTM International, West Conshohocken, PA. 1997.
29. ASTM C944: Standard Test Method for Abrasion Resistance of Concrete or Mortar Surfaces by the Rotating-Cutter Method, ASTM International, West Conshohocken, PA. 2001.

30. Chindaprasirt, P., Jaturapitakkul, C., Sinsiri, T. Effect of Fly Ash Fineness on Microstructure of Blended Cement Paste Construction and Building Materials 21 (7) 2007: pp. $1534-1541$.

https://doi.org/10.1016/j.conbuildmat.2005.12.024

31. Wattanasiriwech, D., Saiton, A., Wattanasiriwech, $\mathbf{S}$. Paving Blocks from Ceramic Tile Production Waste Journal of Cleaner Production 17 (18) 2009: pp. $1663-1668$. https://doi.org/10.1016/j.jclepro.2009.08.008

32. TIS Standard TIS 827: Interlocking concrete paving blocks, Thai Industrial Standard institute, Bangkok, Thailand. 1988.

33. TIS Standard TIS 59: Concrete building brick, Thai industrial Standard instutute, Bangkok, Thailand. 1973.

34. Gencel, O., Ozel, C., Koksal, F., Erdogmus, E., MartínezBarrera, G., Brostow, W. Properties of Concrete Paving Blocks Made with Waste Marble Journal of Cleaner Production 21 (1) 2012: pp. $62-70$. https://doi.org/10.1016/j.jclepro.2011.08.023

35. Norrarat, P. Properties of High Volume Replacement of Fly Ash and Ground Granulated Blast-Furnace Slag Concrete, Master of Construction Engineering Technology Thesis, King Mongkut's University of Technology North Bangkok, 2009.

36. Naik, T.R., Singh, S., Ramme, B.W. Effect of Source of Fly Ash on Abrasion Resistance of Concrete Journal of Materials in Civil Engineering $14(05)$ 2002: pp. $417-426$. https://doi.org/10.1061/(ASCE)0899-1561(2002)14:5(417) 